\title{
Caracterização de isolados de Pantoea ananatis e reação de genótipos de milho à bactéria
}

\author{
Tatiana Borges Silva ${ }^{1}$, Nilvanira Donizete Tebaldi ${ }^{2}$
}

${ }^{1}$ Graduanda em Agronomia, ${ }^{2}$ Professora Associada, do Instituto de Ciências Agrárias, Universidade Federal de Uberlândia, Av. Amazonas s/n, Bloco 2E-121, Campus Umuarama, CEP 38.400-902, Uberlândia, MG, Brasil

Autor para correspondência: Nilvanira Donizete Tebaldi (nilvanira.tebaldi@ufu.br)

Data de chegada: 20/10/2016. Aceito para publicação em: 29/12/2017.

$10.1590 / 0100-5405 / 170862$

\section{RESUMO}

Silva, T.B.; Tebaldi, N.D. Caracterização de isolados de Pantoea ananatis e reação de genótipos de milho à bactéria. Summa Phytopathologica, v.44, n.3, p.283-285, 2018.

A mancha branca do milho, causada pela bactéria Pantoea ananatis é uma das principais doenças foliares da cultura. O uso de variedades resistentes à bactéria é a melhor estratégia para o manejo da doença. Assim, os objetivos deste trabalho foram caracterizar e identificar isolados de Pantoea ananatis e avaliar híbridos de milho resistentes a essa bacteriose. $\mathrm{O}$ isolamento da bactéria foi realizado a partir de folhas de milho com os sintomas de lesões encharcadas. Os isolados bacterianos UFU A18 (Morrinhos-GO) e UFU B13 (Planaltina-GO) foram identificados por meio das características culturais, bioquímicas, moleculares e de patogenicidade em plantas de milho. Os híbridos de milho codificados como A1, A2, B1, $\mathrm{B} 2 \mathrm{e} \mathrm{B} 3$ foram inoculados com os dois isolados bacterianos. O experimento foi conduzido em casa de vegetação em blocos casualizados, em esquema fatorial ( 2 isolados x 5 híbridos) com seis repetições. A severidade da doença foi calculada em quatro avaliações, usando uma escala de notas variando de 0 a 4, calculando-se a área abaixo da curva de progresso da severidade. Os isolados bacterianos foram identificados como Pantoea ananatis e o híbrido de milho A1 mostrou-se resistente à bactéria, quando inoculado com o isolado bacteriano UFU B13.

Palavras-chave: Mancha branca, PCR, Zea mays. \begin{abstract}
v.44, n.3, p.283-285, 2018.
Maize white leaf spot, caused by the bacterium Pantoea ananatis, is one of the main leaf diseases affecting this crop. Using varieties resistant to the bacterium is the best strategy for the disease management. Thus, the aims of this study were to characterize and identify Pantoea ananatis isolates and evaluate maize hybrids resistant to this bacterial disease. The bacterium was isolated from maize leaves showing symptoms of water-soaked lesions. The bacterial isolates UFU A18 (Morrinhos-GO) and UFU B13 (Planaltina-GO) were identified based on cultural, biochemical and molecular characteristics,
\end{abstract}

ABSTRACT

Silva, T.B.; Tebaldi, N.D. Characterization of Pantoea ananatis isolates and reaction of maize genotypes to the bacterium. Summa Phytopathologica,

and pathogenicity in maize plants. The maize hybrids encoded as A1, A2, B1, B2 and B3 were inoculated with two bacterial isolates. The experiment was conducted in a greenhouse in randomized block design and factorial scheme (2 isolates x 5 hybrids) with six replicates. Disease severity was calculated on four evaluations, using a rating scale ranging from 0 to 4 and calculating the area under the severity progress curve. Bacterial isolates were identified as Pantoea ananatis and the maize hybrid A1 was resistant to the bacterium when inoculated with the bacterial isolate UFU B13.

\section{Keywords: white leaf spot, PCR, Zea mays.}

A mancha branca do milho, causada pela bactéria Pantoea ananatis (8) é considerada uma das principais doenças foliares da cultura (5). A doença desenvolve-se em condições de alta precipitação, alta umidade relativa $(>60 \%)$, baixas temperaturas noturnas $\left(14^{\circ} \mathrm{C}\right)$ e pode causar perdas de até $60 \%$ na produção de grãos em cultivares suscetíveis (3).

Segundo Romeiro (10) ainda não se desenvolveu produtos químicos eficientes capazes de curar uma planta ou mesmo de protegê-la contra infecções bacterianas de forma eficiente.

O uso de variedades resistentes é a melhor estratégia para o manejo da doença, por ser mais viável, seguro e de menor impacto ambiental. Nos programas de melhoramento genético, para a obtenção de variedades resistentes deve-se considerar a agressividade do isolados a serem inoculados no hospedeiro. Assim como, a caracterização cultural, bioquímica e molecular dos isolados bacterianos são importantes para a identificação da bactéria.

Portanto, o objetivo deste trabalho foi caracterizar e identificar isolados de Pantoea ananatis obtidos de folhas de milho e avaliar a resistência de híbridos de milho à bactéria.

$\mathrm{O}$ isolamento da bactéria foi realizado a partir de folhas de milho com os sintomas de lesões encharcadas. Fragmentos foliares foram descontaminados com álcool $50 \%$ por 1 minuto, hipoclorito de sódio $2 \%$ por 3 minutos e posterior lavagem em água destilada esterilizada, os quais foram colocados em placa de Petri contendo o meio de cultura 523, e incubados na estufa a $28^{\circ} \mathrm{C}$ por 48 horas.

Os isolados bacterianos obtidos foram caracterizados bioquímica e fisiologicamente pelos testes de: Gram em KOH 3\%, crescimento em meio YDC, oxidação ou fermentação da glicose, motilidade, produção de ácidos a partir de inositol, sorbitol, sucarose e D-arabinose, pela produção da enzima arginina dihidrolase, liquefação da gelatina, oxidase, catalase e crescimento a $37^{\circ} \mathrm{C}(4,8)$. O teste de patogenicidade foi realizado inoculando-se a suspensão bacteriana $\left(10^{8}\right.$ UFC. $\mathrm{mL}^{-1}$, $\left.\mathrm{DO}_{550}=0,5\right)$ dos isolados, por pulverização, em folhas de plantas de 
milho e a reação de hipersensibilidade pela inoculação da suspensão bacteriana em folhas de fumo. A confirmação da identidade dos isolados foi efetuada empregando-se um par de primers ANAF: (5' CGT GAA ACT ACC CGT GTC TGT TGC 3') e EC5: (5' TGC CAG GGC ATC CAC CGT GTA CGC T 3'), para amplificação de um fragmento de $360 / 380$ pares de base (6)

Os isolados foram preservados e mantidos na coleção de trabalho do Laboratório de Bacteriologia do ICIAG/UFU, sob os números UFU A18 e UFU B13, provenientes de Morrinhos (GO) e Planaltina (GO), respectivamente.

Os híbridos de milho codificados como A1, A2, B1, B2 e B3, cedidos pela empresa Syngenta foram cultivados em vasos de $500 \mathrm{~g}$ contendo substrato solo, areia grossa e vermiculita na proporção de $3: 1: 1$, com duas plantas por vaso e foram avaliados quanto à resistência à bacteriose.

Plantas apresentando três a quatro folhas (aproximadamente 15 dias após a semeadura) foram inoculadas com uma suspensão bacteriana $\left(10^{8} \mathrm{UFC} \mathrm{mL} \mathrm{L}^{-1}, \mathrm{OD}_{550}=0,5\right)$ por aspersão. As plantas foram submetidas à câmara úmida $24 \mathrm{~h}$ antes e após a inoculação. $\mathrm{O}$ experimento foi conduzido em delineamento experimental em blocos casualizados, esquema fatorial ( 2 isolados x 5 híbridos), com seis repetições. Onde a unidade experimental constou de um vaso com duas plantas.

A severidade da mancha branca das folhas foi avaliada aos 3, 6, 9 e 12 dias após a inoculação, usando uma escala de notas variando de 0 a 4 , onde: $0=$ folha sem sintoma, $1=$ de 1 a $25 \%$ da folha lesionada, 2 $=$ de 26 a $50 \%$ da folha lesionada, $3=$ de 51 a $75 \%$ da folha lesionada, $4=$ acima de $75 \%$ da folha lesionada.

Para a classificação da reação das plantas foi considerada a avaliação realizada aos oito dias após a inoculação, sendo os híbridos que receberam notas 1 e 2 , considerados resistentes e para notas de 2,01 a 4, considerados suscetíveis.

A Área Abaixo da Curva de Progresso de Doença (AACPD) foi calculada pela fórmula: AACPD $=\sum\left(\left(\mathrm{Y}_{i}+\mathrm{Y}_{\mathrm{i}+1}\right) / 2\right)\left(\mathrm{t}_{\mathrm{i}+1}-\mathrm{t}_{\mathrm{i}}\right)$, onde $\mathrm{Y}$ representa a intensidade da doença, to tempo e i o número de avaliações no tempo (2). Os dados obtidos foram submetidos à análise de variância através do teste de Tukey, a 0,05 de significância, por meio do programa estatístico SISVAR.

Os isolados bacterianos UFU A18 e UFU B13 foram caracterizados cultural, bioquímica e fisiologicamente como: Gram negativo, fermentação da glicose, colônias amarelas em meio YDC, oxidase, catalase, arginina dihidrolase, produção de ácidos à partir do inositol, sorbitol, sacarose, D-arbinose, motilidade, liquefação da gelatina e crescimento a $37^{\circ} \mathrm{C}$, todos positivos. Reação de hipersensibilidade em folhas fumo, positivo e patogenicidade em folhas de plantas de milho, positivo. Nos testes moleculares houve a amplificação de um fragmento de $360 / 380$ pares de base, sendo portanto, os isolados identificados como Pantoea ananatis.

No entanto, para Coplin \& Kado (4) a bactéria Pantoea ananatis apresentou resultado negativo para a reação de hipersensibilidade em folhas de fumo, divergindo dos resultados deste trabalho. A reação de hipersensibilidade positiva em folhas de fumo (7) confirma a patogenicidade dos isolados bacterianos, provenientes de plantas de milho.

Na avaliação da reação de híbridos de milho à Pantoea ananatis (Tabela 1), o híbrido codificado A1 $(1,22)$ mostrou-se resistente ao isolado UFU B13, enquanto que os demais híbridos codificados foram suscetíveis aos dois isolados bacterianos. Também Brito et al. (1) diferenciaram híbridos de milho resistentes e suscetíveis à Pantoea ananatis. A utilização de híbridos de milho resistentes à bactéria pode reduzir a incidência da mancha branca no campo.
Tabela 1. Reação de híbridos de milho à Pantoea ananatis, aos oito dias após a inoculação por aspersão.

\begin{tabular}{ccc}
\hline \multirow{2}{*}{ Híbridos } & \multicolumn{2}{c}{ Isolados } \\
\cline { 2 - 3 } & UFU A18 & UFU B13 \\
\hline A1 & $3,55^{*}(\mathrm{~S})$ & $1,22(\mathrm{R})$ \\
A2 & $3,78(\mathrm{~S})$ & $2,66(\mathrm{~S})$ \\
B1 & $3,94(\mathrm{~S})$ & $2,72(\mathrm{~S})$ \\
B2 & $3,83(\mathrm{~S})$ & $3,00(\mathrm{~S})$ \\
B3 & $3,94(\mathrm{~S})$ & $3,83(\mathrm{~S})$ \\
\hline
\end{tabular}

*Escala de notas de 0 (folha sem sintomas) a 4 (acima de $75 \%$ da folha lesionada). $\mathrm{S}=$ suscetível, $\mathrm{R}=$ resistente. Média das 6 repetições.

Para a área abaixo da curva de progresso da severidade (AACPS) da mancha branca do milho (Tabela 2 ), não houve diferença significativa entre os híbridos testados quando inoculados com o isolado UFU A18, onde a AACPS variou de 33,23 (híbrido A1) a 35,24 (híbrido B1). No entanto, para o híbrido codificado A1 $(10,82)$ quando inoculado com o isolado UFU B13 houve uma menor AACPS, diferindo estaticamente dos demais. O isolado bacteriano UFU B13 de Pantoea ananatis apresentou menor agressividade ao híbrido de milho A1 $(10,82)$, que o isolado UFU A1 8 para o mesmo híbrido $(33,23)$. O híbrido codificado A1 pode apresentar genes que codificam proteínas de defesa da planta ao isolado UFU B13.

Tabela 2. Área abaixo da curva de progresso da severidade (AACPS) da mancha branca do milho, para diferentes híbridos e dois isolados bacterianos.

\begin{tabular}{ccc}
\hline \multirow{2}{*}{ Híbridos } & \multicolumn{2}{c}{ Isolados } \\
\cline { 2 - 3 } & UFU A18 & UFU B13 \\
\hline A1 & $33,23 \mathrm{aA}$ & $10,82 \mathrm{bB}$ \\
$\mathrm{A} 2$ & $34,07 \mathrm{aA}$ & $25,55 \mathrm{aB}$ \\
$\mathrm{B} 1$ & $35,24 \mathrm{aA}$ & $28,64 \mathrm{aA}$ \\
$\mathrm{B} 2$ & $34,40 \mathrm{aA}$ & $28,30 \mathrm{aA}$ \\
B3 & $34,90 \mathrm{aA}$ & $33,40 \mathrm{aA}$ \\
\hline Média dos isolados & $34,36 \mathrm{~A}$ & $25,34 \mathrm{~B}$ \\
\hline
\end{tabular}

CV (\%): 17,04

Médias seguidas por letras distintas, minúsculas na coluna e maiúsculas na linha, diferem entre si pelo teste de Tukey a 0,05 de significância.

Para a AACPS da mancha branca do milho houve diferença significativa entre isolados bacterianos (Tabela 2), a quantidade média de doença do isolado UFU A18 $(34,36)$ foi significativamente maior que o isolado UFU B13 $(25,34)$. De maneira geral, o isolado UFU A18 foi mais agressivo para todos os genótipos avaliados, quando comparado com o isolado UFU B13.

A variação do híbrido codificado A1 (Tabela 2), em apresentar suscetibilidade e resistência, aos isolados UFU A18 e UFU B13, respectivamente, indica a possibilidade do patógeno possuir raças, com diferentes níveis de virulência. De acordo com Brito et al. (1) provavelmente devido alterações na população do patógeno por pressão de seleção direcional, em favor de raças mais agressivas, acelerada 
pelo aumento de fonte de inóculo no campo, em função de plantios sucessivos de safra e safrinha, ausência de rotação de cultura e utilização frequente de fungicidas.

Até o momento, ainda não foi descrito a ocorrência de raças de Pantoea ananatis na cultura do milho no Brasil. Outros ensaios deverão ser conduzidos com outros híbridos de milho e um maior número de isolados de Pantoea ananatis, para confirmar a agressividade dos isolados de diferentes regiões do país e a possibilidade de raças do patógeno.

De acordo com Rocha \& Paccola-Meirelles (9), a Pantoea ananatis é uma bactéria epifítica, com propriedades de nucleação do gelo, com um aumento populacional crescente à medida que o milho atinge a fase de pré-florescimento, e em condições climáticas favoráveis ocorrerá o desenvolvimento de lesões foliares encharcadas.

A identificação de Pantoea ananatis e a utilização de isolados bacterianos com diferentes níveis de virulência ou até mesmo a possibilidade de raças do patógeno poderá auxiliar os programas de melhoramento genético, na seleção de híbridos de milho resistentes à bactéria.

O híbrido de milho codificado $\mathrm{A} 1$ mostrou-se resistente à Pantoea ananatis, quando inoculado com o isolado bacteriano UFU B13.

\section{REFERENCIAS}

1. Brito, A.H.; von Pinho, R.G.; Santos, A.O. Santos, S. Reação de híbridos de milho e comparação de métodos para avaliação da Cercosporiose e Mancha Branca. Tropical Plant Pathology, Brasília, DF, v.36, n.1, p.35-41, 2011.

2. Campbell, C.L.; Madden, L.V. Introduction to plant disease epidemiology. New York: Jonh Wiley, 1990. 532p.

3. Casela, C.R.; Ferreira, A.S.; Pinto, N.F.J.A. Doenças na cultura do milho. Sete Lagoas: Embrapa, 2006. (Circular Técnica, 83).

4. Coplin, D.L.; Kado, C.I. Gram-negative bacteria: Pantoea. In: Schaad, N.W.; Jones, J.B.; Chun, W. (Ed.). Laboratory guide for identification of plant pathogenic bacteria. St. Paul: APS. 2001. p.73-83

5. Costa, R.V.; Cota L.V.; Silva; D.D.; Lanza, F.E.; Figueiredo, J.E.F. Eficif ência de fungicidas para o controle da mancha branca do milho. Revista Brasileira de Milho e Sorgo, Sete Lagoas, v.11, n. 3, p.291-301, 2013.

6. Figueiredo, J.E.F.; Paccola-Meirelles, L.D. Simple, rapid and accurate PCR-based detection of Pantoea ananatis in mayze, sorghum and Digitaria sp. Journal of Plant Pathology, Pisa, v.94, n.3, p.663-667, 2012.

7. Mariano, R.L.R.; Silveira, E.B. Manual de práticas em fitobacteriologia. 2.ed. Recife: UFRPE, 2005. 184p.

8. Paccola-Meirelles, L.D.; Ferreira, A.S.; Meirelles, W.F.; Marriel, I.E.; CaseE la, C.R. Detection of a bacterium associated with a leaf spot disease of maize in Brazil. Journal of Phytopathology, Berlim, v.149, n.5, p.275-279, 2001.

9. Rocha, K.R.; Paccola-Meirelles, L.D. Efeito do tamanho populacional de Pantoea ananatis na atividade de ice nucleation e reprodução dos sintomas dos sintomas da mancha branca do milho. In: Encontro Anual de Iniciação Científica, 18., 2009, Londrina. Anais. Londrina: UEL, 2009. 1 CD-ROM. 10. Romeiro, R.S. Bactérias fitopatogênicas. 2.ed. Viçosa: UFV, 2005. 417p. 